\title{
Typification of Fritillaria tubiformis Gren. \& Godr., Fritillaria delphinensis f. moggridgei Planch. and Fritillaria delphinensis var. burnatii Planch. (Liliaceae) from SW Europe
}

\author{
Fabrizio Bartolucci \& Lorenzo Peruzzi
}

\section{Abstract}

BARTOLUCCI, F. \& L. PERUZZI (2012). Typification of Fritillaria tubiformis Gren. \& Godr., Fritillaria delphinensis f. moggridgei Planch. and Fritillaria delphinensis var. burnatii Planch. (Liliaceae) from SW Europe. Candollea 67: 23-29. In English. English and French abtracts.

The names of Fritillaria tubiformis Gren. \& Godr., Fritillaria delphinensis f. moggridgei Planch. and Fritillaria delphinensis var. burnatii Planch. are lectotypified. Comments are given on the taxonomic value and systematic status of the three taxa.

\section{Résumé}

BARTOLUCCI, F. \& L. PERUZZI (2012). Typification de Fritillaria tubiformis Gren. \& Godr., Fritillaria delphinensis f. moggridgei Planch. et de Fritillaria delphinensis var. burnatii Planch. (Liliaceae) du SO de l'Europe. Candollea 67: 23-29. En anglais, résumés anglais et français.

Les noms de Fritillaria tubiformis Gren. \& Godr., Fritillaria delphinensis f. moggridgei Planch. et de Fritillaria delphinensis var. burnatii Planch. sont lectotypifiés. Des commentaires sont donnés sur la valeur taxonomique et systématique de ces trois taxons.

\section{Key-words}

LILIACEAE - Fritillaria - Typification

Addresses of the authors: FB: Centro Ricerche Floristiche dell'Appennino (Parco Nazionale del Gran Sasso-Monti della Laga - Dipartimento di scienze Ambientali dell' Università di Camerino), San Colombo, I-67021, Barisciano (L'Aquila), Italy. E-mail: fabrizio.bartolucci@gmail.com

LP: Dipartimento di Biologia, Unità di Botanica generale e sistematica, Università di Pisa, I-56126, Pisa, Italy. 


\section{Typification}

1. Fritillaria tubiformis Gren. \& Godr. in Mém. Soc. Emul. Doubs ser. 2, 6: 13. 1855.

$\equiv$ Fritillaria delphinensis Gren. in Gren. \& Godr., Fl. France 3: 180. 1855, nom. illeg.

Lectotypus (here designated): France. Hautes Alpes: Lusette en Luz (Drome), 1847, Boullu s.n. (P! ex Herb. Grenier sub F. meleagris, rev. F. alpicola) (Fig. 1).

Syntypi. - France. Hautes Alpes: Mt. Seuse pres Gap, VIII.1847, Verlot s.n. (P! ex Herb. Grenier, sub F. meleagris, rev. F. alpicola); Mt. Séuse près Gap, 1854, Grenier s.n. (K!).

GRENIER \& GODRON (1855) quote several syntypes for this taxon. From the localities cited in the protologue, we traced, in $\mathrm{P}$ and $\mathrm{K}$, specimens that can be considered as original material. Among these we choose the most well-developed and well-presented as lectotype.

Taxonomic discussion. - Fritillaria tubiformis was long confused with F. meleagris L. (i.e., BERTOLONI, 1839), but it is clearly distinct from all other species from West Europe (GRENIER \& GODRON, 1855). On the other hand, it seems close to F. latifolia Willd., widespread from Caucasus to N Turkey (RIX, 2001), from which it differs in having glaucous leaves (vs. shiny green) and shorter style branches. Among the taxa usually synonymized with $F$. tubiformis, two seem to deserve special attention ( $F$. delphinensis var. burnatii Planch. and F. delphinensis f. moggridgei Planch.), while others have doubtful taxonomic value (i.e., F. delphinensis var. reverchonii Rouy; RouY, 1910). Similarly to what was done recently with the F. montana W. D. J. Koch complex (BARTOLUCCI \& al., 2009; Peruzzi \& al., 2009; PeruzZi \& Bartolucci, 2009), a biosystematic study is in progress about the $F$. meleagris $\mathrm{L}$. complex (F. meleagris s.l. and F. tubiformis s.1.), aiming to clarify the relationships among the taxa and their distribution.

2. Fritillaria delphinensis f. moggridgei Planch. in Bull. Soc. Bot. France 20: 116. 1873.

$\equiv$ Fritillaria delphinensis var. moggridgei (Planch.) Nyman, Consp. Fl. Eur.: 722. 1882.

$\equiv$ Fritillaria delphinensis subsp. moggridgei (Planch.) K. Richt., Pl. Eur. 1: 212. 1890.

$\equiv$ Fritillaria tubiformis var. moggridgei (Planch.) Rouy, Fl. France 12: 404. 1910.

$\equiv$ Fritillaria tubiformis subsp. moggridgei (Planch.) Rix in Bot. J. Linn. Soc. 76: 356. 1978.

Lectotypus (here designated): ITALY. Maritime Alps: Col de Carbon, près le val Pesio (Prov. de Cuneo), Piémont, 29.VII.1872, E. Burnat s.n., with note “j'ai encore trouvé cette espèce dans le val Cravina (du Val Pesio), près le Col (Il Colle) entre Pesio et Limone, puis dans le fond du val del Pian del Creuzo (val Pesio) et enfin au Pied du Mont Cars au-dessus de la Chartreuse de Pesio" (G-BU! individual on the left; iso-: G-BU! individual on the right) (Fig. 2, arrow).

Syntypi. - France. Maritime Alps: M. Authion, Alpes Mtes, 26.IV.1867, M. Moggridge s.n. (G-BU!);

ITALY. Maritime Alps: Sommites au-dessus de la Chartreuse de Pesio (Prov. de Cuneo, Piemont), 6.VII.1872, E. Burnat s.n. (G-BU!); Chartreuse de Pesio près Coni (Vallone de Marguarès), 22.VI.1862, s.coll. (in Herb. Thuret, G-BU!, sub F. lutea M. Bieb.); Vallon de Pari, près le Chartreuse de Pesio, 2.VII.1862, s.coll. (in Herb. Thuret G-BU!, sub F. lutea M. Bieb.); ravins situés au-dessus de la bergerie de Breglio (Alpes de Breglio) près des neiges fondantes, 23.VI.1860, Canut s.n. (G-BU!); un seul exemplaire au bas d'un couloir descendant dans le val Pesio près Cuneo, sans doute descendu des hauteurs voisines avec une avalanche, 14.VI.1872, E. Burnat s.n. (G-BU!); Sommites au-dessus de la Chartreuse de Pesio (Prov. de Cuneo, Piemont), 6.VII.1872, E. Burnat s.n. (FI!, MPU!).

Iconography. - MoGGRIDGE (1864: plate XXV, sub F. delphinensis Gren.?) published a plate which illustrates specimens gathered "from a mountain not far from Giandola in the Sospello valley" (Fig. 3).

In the protologue, PLANCHON (1873) quoted, for this taxon, several type localities (gatherings in Herb. Thuret, G-BU) from the Maritime Alps and also the Moggridge's iconography cited above, which is consequently original material for the name. Moreover, we traced in G-BU, MPU and FI specimens, from the cited localities, that completely fit with the protologue and then can be considered as original material too (syntypes). Among these, only one specimen, conserved in G-BU, is labelled as F. delphinensis y moggridgei [manu Planch.] (January, 1873). The complete individual on the left is chosen as the lectotype.

Taxonomic discussion. - This taxon was treated, in the past, in different ways: as a subspecies (i.e., RIX, 1978), a variety (i.e., Fiori, 1923; PignatTi, 1982) or fully synonymic (i.e., AEschimann \& al., 2004) with F. tubiformis. The study of the selected lectotype and of the other available original material clearly shows that this taxon is closer to F. tubiformis than to any other European species. However, the two seem to be very distinct for many character-states. Our preliminary results confirm this view. Nowadays, there is some doubt about the relations between F. tubiformis subsp. moggridgei and F. collina Adam (=F. lutea M. Bieb.). The latter species, widespread in Caucasus (RIX, 2001), has yellow-greenish flowers and inner tepals with ciliate margins.

Specimina visa. - France. Maritime Alps: Mentone, 5000 [...], s.d., M. Moggridge s.n. (Herb. Hookerianum 1867, K!); Col de Tende, summer 1870 , collected by the Landlord of the Ro. Grass Recovers (sub F. lutea M. Bieb.) (FI!, G-BOI!, G-DC!, G (Herb. Reuter Barbey)!). 


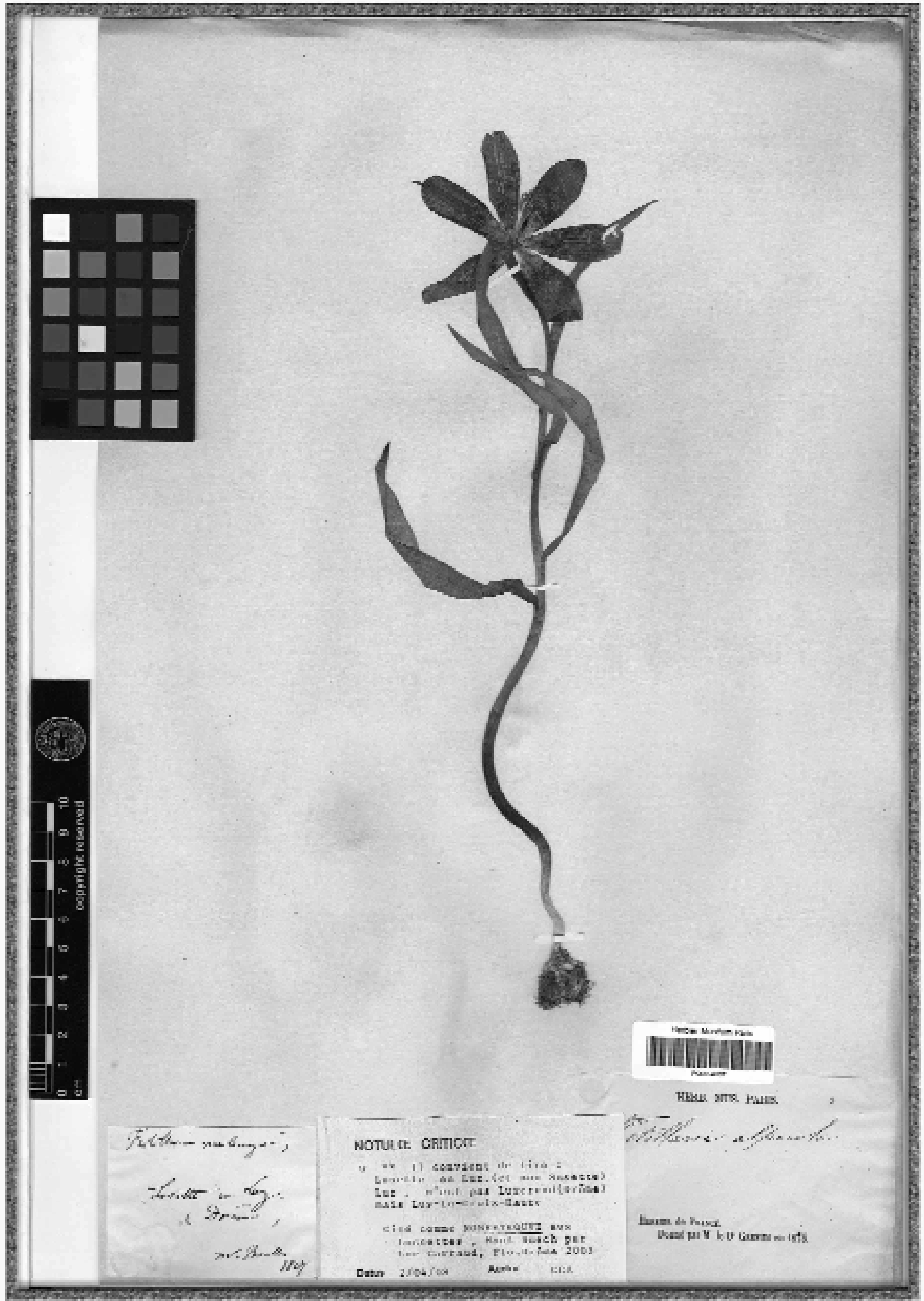

Fig. 1. - Lectotypus of the name Fritillaria tubiformis Gren. \& Godr.

[Boullu s.n., P] [@ Museum National d'Histoire Naturelle, Paris. Reproduced with permission] 


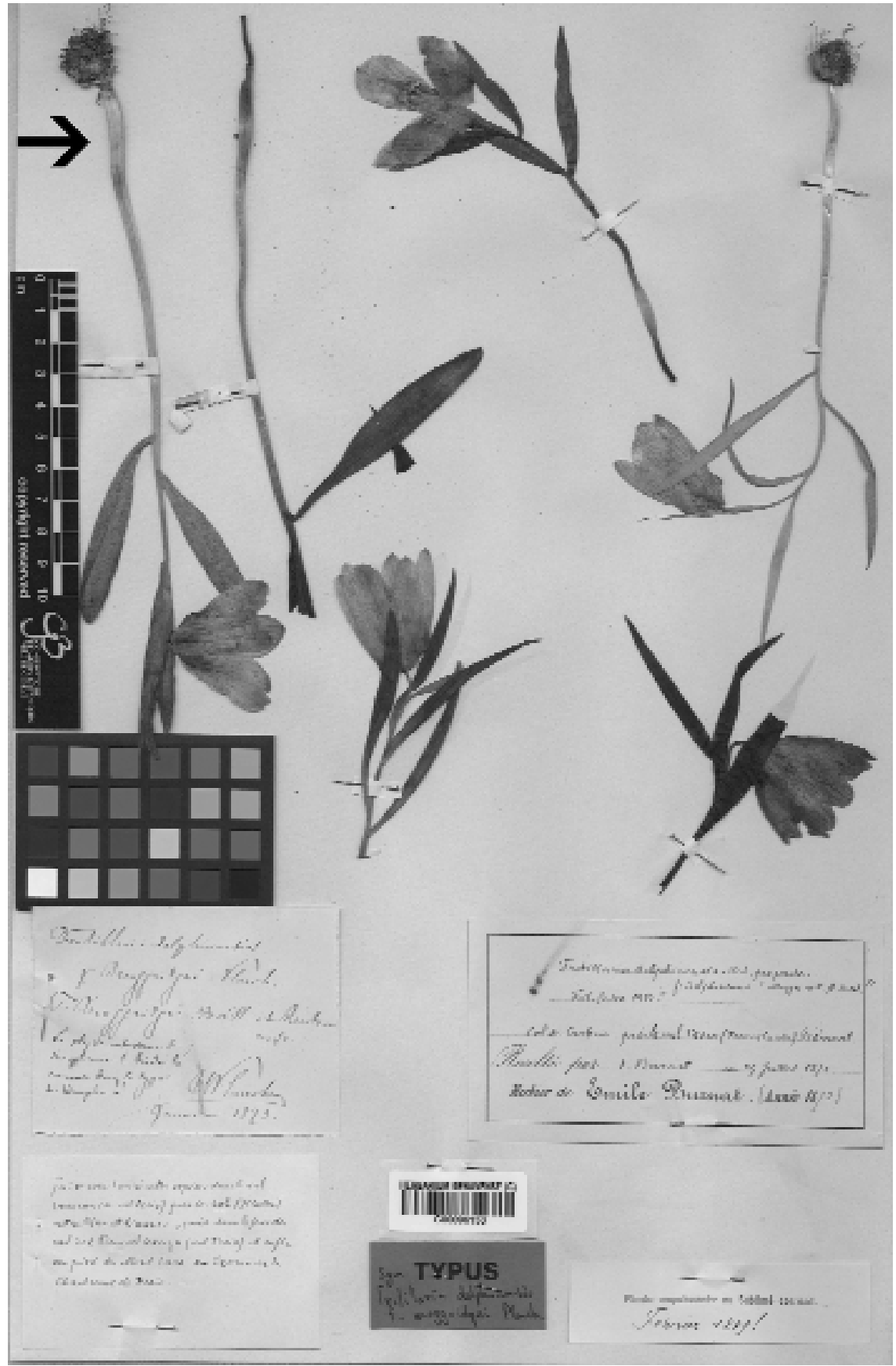

Fig. 2. - Lectotypus of the name Fritillaria delphinensis f. moggridgei Planch.

[E. Burnat s.n., G-BU] [@ Conservatoire et Jardin botaniques de la Ville de Genève] 


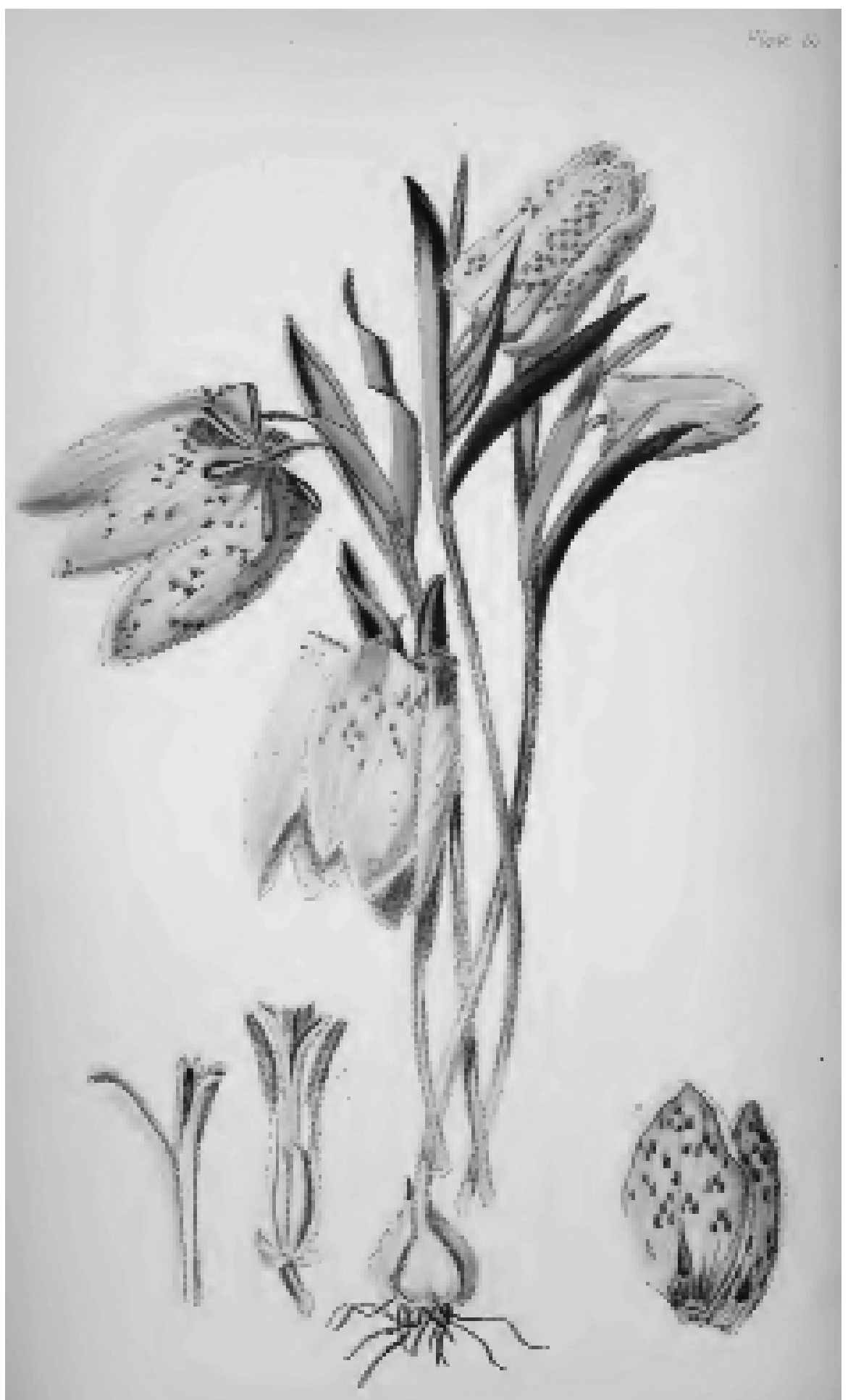

Fig. 3. - Iconography of "Fritillaria delphinensis Gren.?", published by MOGGRIDGE (1864: plate XXV), which is also original material for F. delphinensis f. moggridgei Planch. 
3. Fritillaria delphinensis var. burnatii Planch. in Bull. Soc. Bot. France 20: 115. 1873.

$\equiv$ Fritillaria delphinensis subsp. burnatii (Planch.) K. Richt., Pl. Eur. 1: 212. 1890.

$\equiv$ Fritillaria tubiformis var. burnatii (Planch.) Rouy, Fl. France 12: 403. 1910.

$\equiv$ Fritillaria meleagris subsp. burnatii (Planch.) Rix in Bot. J. Linn. Soc. 76: 356. 1978.

Lectotypus (here designated): France. Maritime Alps: Pâturages au mont Piernaude près le col de Tende, 29.VI.1861, E. Borgeau 346 (G-BU!, complete individual on the right; iso-: FI!, G!) (Fig. 4, arrow).

Syntypi. - France. Maritime Alps: Sommites voisines du col de Tende, route de Margherita di Caramagna, 30.VI. 1872, E. Burnat s.n. (G-BU!, G! sub F. sp. nov.?/F. meleagris All. herb. pr. Parte, MPU!); Sommites voisines du col de Tende (Piemont), dans les paturages secs (sur la route entre le sommes du Col et Margherita di Caramagna), 30.VI.1872, E. Burnat s.n. (K! sub F. allionii Planch. ined.).

In the protologue, PLANCHON (1873) quotes several type localities in the Maritime Alps and only two collections (29.VI.1861, Borgeau 346 in Herb. Thuret and 30.VI. 1872, Burnat s.n. in Herb. Thuret). We traced in G-BU, K, MPU and FI specimens, from the cited localities, that can be considered as original material (syntypes). Among these, there is one in G-BU, which is labelled as $F$. delphinensis var. burnatii manu Planch. (January, 1873). The complete individual on the right is chosen as the lectotype.

Taxonomic discussion. - Fritillaria meleagris subsp. burnatii has long been confused with other close taxa (in herbaria checked by us: F. meleagris L., F. involucrata All. and F. delphinensis or fully synonymized with $F$. tubiformis , mostly by Italian botanists (i.e., FIORI, 1923; ZANGHERI, 1976; PIGNATTI, 1982). After study of the selected lectotype and of the other available original material we are convinced that $F$. meleagris subsp. burnatii is an independent taxon actually closer to F. meleagris than to F. tubiformis. This hypothesis agrees with RIX (1978) in considering this unit as a subspecies of $F$. meleagris. Anyway, further studies aimed at clarifying the taxonomic value, the systematic status and the actual distribution of this taxon are in progress.

Specimen visum. - France. Maritime Alps: Col de Tende, Alpes Maritimes, fin VI.1868, Burnat s.n. (FI!).

\section{Acknowledgements}

Curators of FI, G, K, LY, MPU, P, RO herbaria are gratefully acknowledged. The authors wish to thank also Dr Jean-Marc Tison (L'Isle d'Abeau, France) for his kind help in finding precious bibliographic references.

\section{References}

Aeschimann, D., K. Lauber, D. Martin Moser \& J. P. Theurillat (2004). Fl. Alpina 2. Zanichelli, Bologna.

Bartolucci, F., K. F. Caparelli \& L. Peruzzi (2009). A biometric study of Fritillaria montana Hoppe ex W. D. J. Koch s.1. (Liliaceae) shows a single polymorphic species, with no infraspecific taxa. Pl. Biosyst. 143: 516-527.

Bertoloni, A. (1839). Fl. Italiana 4: 73-76. Bologna.

FIORI, A. (1923). Nuova Fl. Analitica Italia 1 : 248-250. Firenze.

Grenier, J. C. M. \& D. A. Godron (1855). Notices botaniques sur quelques plantes des genres Fritillaria, Asphodelus et Melica. Mém. Soc. Émul. Doubs ser. 2, 6: 12-15.

Moggridge, J.-T. (1864). Contributions to the flora of Mentone and to a winter flora of the Riviera, including the coast from Marseilles to Genoa. Fasc. I (Plate I-XXV). London.

PeruZzi, L. \& F. BARTOLUCCI (2009). Typification of the names within Fritillaria montana complex (Liliaceae) from central Mediterranean area. Candollea 64: 133-142.

Peruzzi, L., K. F. Caparelli \& F. Bartolucci (2009). Fritillaria messanensis subsp. neglecta (Parl.) Nyman, a fourth subspecies within Fritillaria messanensis (Liliaceae) from NW Balkans. Candollea 64: 237-244.

Pignatti, S. (1982). Fl. Italia 3: 360-361. Edagricole.

Planchon, J. E. (1873). Sur les espèces de fritillaries de France, a propos des icones et d'un manuscrit inédit de Pierre De Belleval. Bull. Soc. Bot. France 20: 96-124.

RIX, E. M. (1978). Short notes (Liliaceae). Bot. J. Linn. Soc. 76: 356.

RIX, E. M. (2001). Fritillaria. A revised classification. The Fritillaria Group of the Alpine Garden Society, United Kingdom.

RouY, G. (1910). Fl. France 12: 401-405. Paris.

Zangheri, P. (1976). Fl. Italica 1: 849-850. CEDAM, Padova. 


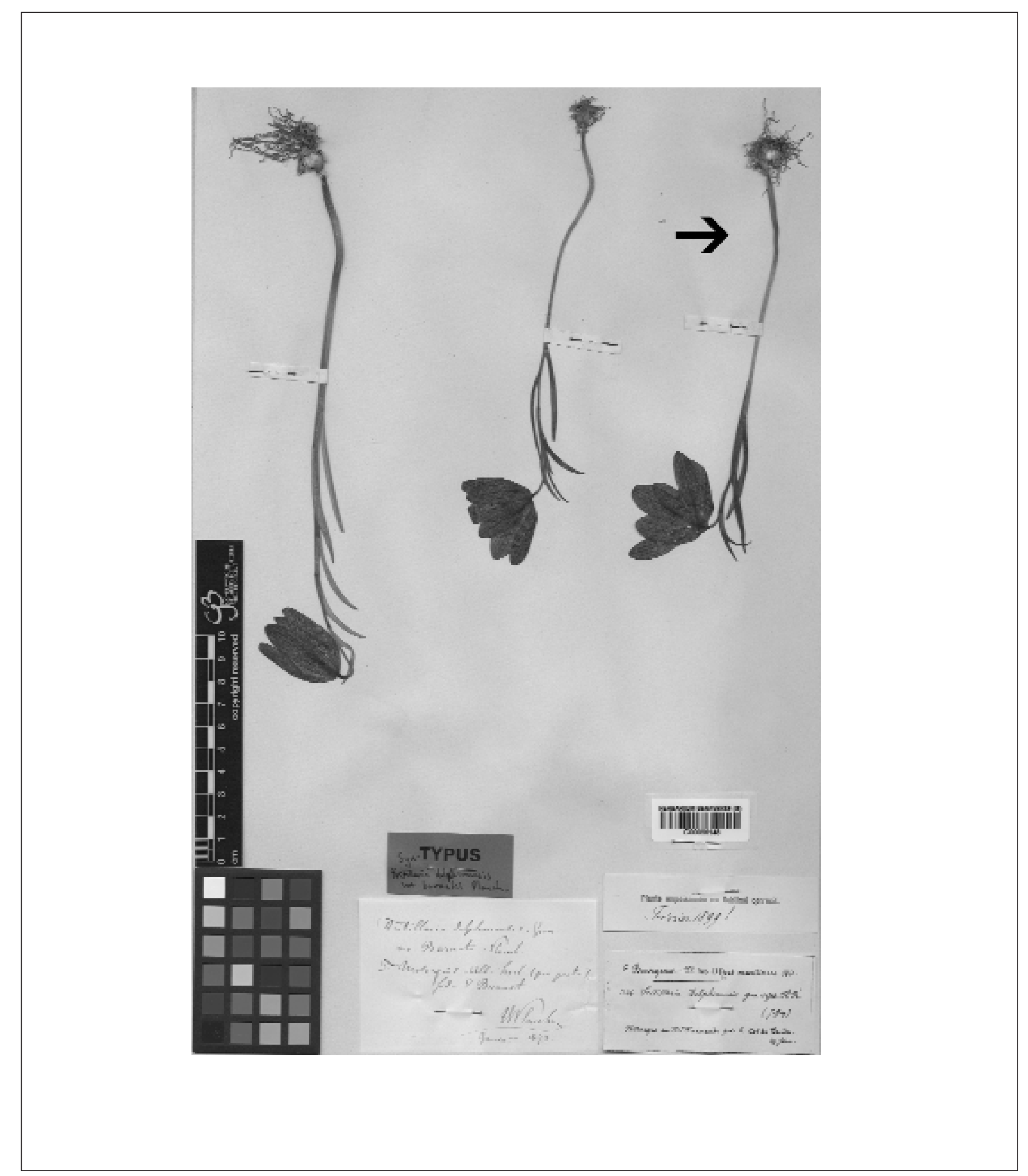

Fig. 4. - Lectotypus of the name Fritillaria delphinensis var. burnatii Planch.

[E. Borgeau 346, G-BU] [@ Conservatoire et Jardin botaniques de la Ville de Genève] 
